Volume 5

Issue 2 Kate Millett Memorial Issue

Article 14

$10-2020$

\title{
Reflections By Linda Clarke: Kate Millett Memorial Service
}

Linda Clarke

Follow this and additional works at: https://digitalcommons.uri.edu/dignity

\section{Recommended Citation}

Clarke, Linda (2020) "Reflections By Linda Clarke: Kate Millett Memorial Service," Dignity: A Journal of Analysis of Exploitation and Violence: Vol. 5: Iss. 2, Article 14. https://doi.org/10.23860/ dignity.2020.05.02.14

This Kate Millett Memorial Issue is brought to you for free and open access by DigitalCommons@URI. It has been accepted for inclusion in Dignity: A Journal of Analysis of Exploitation and Violence by an authorized editor of DigitalCommons@URI. For more information, please contact digitalcommons-group@uri.edu. 


\section{Reflections By Linda Clarke: Kate Millett Memorial Service}

Creative Commons License

(c) (i)@(ङ)

This work is licensed under a Creative Commons Attribution-Noncommercial-No Derivative Works 4.0 License. 


\title{
DIGNITY
}

Volume 5, Issue 2, Article 14, 2020

https://doi.org/10.23860/dignity.2020.05.02.14

\section{REFLECTIONS BY LINDA CLARKE: KATE MILLETT MEMORIAL}

\author{
Linda Clarke \\ Farm Mother
}

$\mathrm{W}$ HEN KATE MILLETT AND I MET almost 50 years ago, she was feverishly busy, cheerful, interviewing prostitutes from the back of her Buick convertible, tearing wallpaper off the old walls of a farmhouse, walking to Albany in support of gay candidates, and planning a movie about three women living in America. I couldn't keep track. I was on my way to exploring another way of life, the practice of non-thinking (meditation) as opposed to critical thinking. We were on wildly different paths; even so, we instantly enjoyed a remarkable and mysterious connection.

She was celebrating the early success of Sexual Politics and forming life-long friendships in what was the first lesbian feminist CR [consciousness raising] group in New York City, which included Barbara Love, Sidney Abbott, Jane O’Wyatt, Phyllis Birkby, Nath Rockhill, and Alma Routsong. After our meeting, we trooped over to a women's bar on 14th street and danced to The Night They Drove Old Dixie Down. There were other women there, furtive, in corners, dykes in the old sense. But we were from another planet. We had discovered sisterhood. The burly guys at the door left us alone. It was a wonderful time to be alive.

Kate was an improbable celebrity, a spokesperson for feminism. Her phone was always ringing, which was one reason she liked to visit me just around the corner from the Bowery loft she shared with Fumio because my apartment was above the Marble Cemetery of New York, the city's oldest and perhaps quietest cemetery.

She was first and foremost an intellectual, a bookworm at the top of her form, but no ordinary one. Nobody in the world could pinpoint the disingenuousness and general wrong-headedness of politicians with her brio and energy. Our breakfasts perusing The New York Times were filled with hilarity, scrambled eggs, coffee, buttered toast, and heavy cream. An old lawnmower wheezed back and forth in Marble Cemetery below, the caretaker coughing every now and then. How young and strong we felt; how superior to the old and the dead.

It was Christopher Leman Haupt's extraordinary review of Sexual Politics in The Times that turned a lot of people on to Kate and maybe to feminism as well. Haupt had just been promoted senior daily book reviewer of the newspaper and was about Kate's age. His stunning review took two successive days in the paper after which he went trout fishing with his buddies and, he writes with some astonishment, they spent the entire weekend debating Kate's conclusions.

We, too, always talked about what we were reading. I introduced her to Gandhi's Truth by Eric Erickson and the new biography of Leo Tolstoy by Henri Troyat. 
In authentic Olde English, Kate would recite portions of The Canterbury Tales. She insisted I read Violet Leduc's La Batarde. She was extraordinarily taken with Leduc's raw confessional, somewhat messy style. The whole trajectory of her writing career was now profoundly influenced by this protégé of Simone de Beauvoir. No more Mandarin prose of Sex Pol as Kate now dismissively referred to her first success.

I took Kate to see Dorothy Day, whose House of Hospitality was on East 1st Street, where I helped out on the soup line. It was thrilling to see them, the social reprobate and the Servant of God, sitting close together at a long table, chainsmoking and talking in low voices about non-violence for hours.

They both lived on the Bowery, political radicals committed to social justice and human dignity. Dorothy Day of the Catholic Worker defended the poor and forsaken. Kate fought for the rights of women, lesbians, gays, sex workers, the elderly, the tortured, and the mentally ill. Dorothy Day has since been recognized by the Church as living a life of "heroic virtue" and is on the path to sainthood.

Before graduating from Oxford in 1956, Kate had been greatly affected and formed by Anne Eliot, one of St Hilda's Tutorial Fellows in English Literature, a universally adored advisor who she met once a week in Eliot's rooms where they would sit before a fire, smoking American cigarettes and where Kate first read from a tentative essay, the initial stages of, believe it or not, Sexual Politics

Suddenly finding her present life an agitating exhausting overwhelming circus of phone calls, agents, media demands, interviews, and mountains of fan mail, Kate remembered Eliot with melancholy nostalgia. She had known her when her life had been calm and steady and reflective.

Eliot was a gentle and wise English Christian who specialized in Edmund Spencer's The Faerie Queen (which Kate laughingly described as one of the longest poems in the English language and entirely devoted to considering particular virtues)

Ironically, it was this humble tutor, a perfect lady in every sense, who was probably the first to hear and supervise some of the ferocious language forming the spine of a book that eventually became such a favorite with the guys on trout fishing weekends. (Anne Elliot died in the summer of 2002, inspired a garden named after her by her legions of admiring students. Even near the end of her life, she always proudly remembered: "dear Kate.”)

I mention her here because I believe she was primarily responsible for helping Kate to value a sense of good will, which she talked about in these early days of our friendship and at our CR [consciousness raising] group and in that badly lit women's bar owned by the Mafia.

Perhaps our most important bond was that we both were occupied with what we called VERITAS, what it was, how to acquire it, how it's lost. The qualities I most cherished about the early Kate were her exquisite clarity of mind, her sense of the absurd, and her moral judgment, which I deemed infallible. I shared her sense of the absurd, made her laugh, and she thought I was kind. She began calling me "Clarkie."

Influenced by Leduc's "terrible candor," she exposed in her next books the most personal aspects of her emotional, sexual, and psychological life to a social landscape that was hostile. Kate experienced a cruel in your face pushback that left her vulnerable. 
Thus, her real pilgrimage had begun as had mine. In 1972, I took a ten-year hiatus in ashrams and reluctantly abandoned the lower East side, the feminist movement, my CR group, and most especially Kate, who soon left for an extended stay in California.

About half-way thru my self-imposed exile, Kate returned and found me in my urban ashram in Queens. She was dealing unsuccessfully with acute manic depression and was talking too fast and had acquired a menacing tone I was not used to. Looking worn out and rumpled, she described how people complained when she didn't wear pants at the Farm and the police were constantly being called. I was working at a place called Guru Health Foods, wearing a sari and sneakers, making endless bags of fruit and nut mix and trying to become a vegetarian by eating cashews and dried pineapple. We became hysterical trying to figure out what had happened to our lives and who was "crazier."

When she finally drove away, top down, black hair flying in the wind, she shouted over her shoulder: "Clarkie! Call me when you find something!"

When I returned from India, I rejoined Kate and her new love, Sophie Kier, lived in the philosophy book section of their Bowery loft and became "the mother" of the Farm. At the Farm, Kate was finally president of her own university. She created a special curriculum for women artists and writers from all over the world. How to be intrepid, how to create and appreciate beauty, how to endure physical, impossibly difficult labors. How to survive heat, ticks, poison ivy, exhaustion, each other. How to be radicals by going to the root of everything.

Sophie was the chief engineer, the general contractor, master plumber and electrician, soother of souls, and anything else she needed to be.

I emptied ashtrays, cooked lots of meat, kept naked women out of the kitchen, swam with Kate reflecting on each day, and presided over the dining room conversation, constantly trying to raise the tone.

The loosestrife, the Elm over the pond, the light, the great blue heron, champagne on sunset hill, the sounds of women's laughter through open windows, the growing confidence. Everyone who came to the Farm was altered. Each one of you, in your own way has moved us forward.

Today we are here to celebrate this wayward American original who so successfully struggled with the conservative canon at Oxford, who learned to drive a tractor up and down steep hills, who planted, harvested, and sold Christmas trees; who wrote 11 books translated into nine languages, who created and led a utopian women's artist and writers colony, and built her own silkscreen and sculpture studios, who defied every convention, who changed our world, all the while dealing with an unruly mind.

In 1981 she hastily wrote in pencil under a little watercolor of her red tractor:

Everyday holding it together,

Just as it comes apart again

Another leaves, something else

breaks or won't start

The money's gone or

the weather turns against us

Big as life this farm

filling the whole sky with passion 
Some might deny my friend lived the life of heroic virtue she so desperately craved. But no one can ever deny that Kate Millett was big as life.

\section{AUTHOR BIOGRAPHY}

Linda Clarke was the "Farm Mother" on Kate Millett's farm.

\section{RECOMMENDED CITATION}

Clarke, Linda. (2020). Reflections by Linda Clarke: Kate Millett memorial service. Dignity: A Journal of Sexual Exploitation and Violence. Vol. 5, Issue 2, Article 14. https://doi.org/10.23860/dignity.2020.05.02.14 Available at http://digitalcommons.uri.edu/dignity/vol5/iss2/14. 